\title{
10
}

\section{Epilogue: A Century of Norwegian Shipping}

At the start of this book, I suggested that Norway's strong position in international shipping at the beginning of the 20th century was based on a combination of favourable geographical circumstances, a historical legacy and a strong maritime culture. At the end of the 20th century, these factors still played important roles, though they had changed dramatically over the past 100 years.

The geographical circumstances were originally related to the long coast- "Highway No. 1, the way to the north" - that had given Norway its name. The coast made maritime skills a necessity. However, by the end of the century the geographic dimension included not only the sheltered sea lane and the rich fisheries, which had been so important during previous centuries. Now, as a result of improvements in technology, the favourable geography also included the vast exploitable petroleum resources below the seafloor on the Norwegian continental shelf. These resources have laid the fundament for new maritime activity and for new international expansion. The sea is no longer as present in Norwegian daily life as it was in the sailing ship era, when there was a sailor in most families along the coast in the southern part of Norway and a fisherman in most families in the north. However, the bounties of the sea are more visible in 
Norwegian statistics than ever before, and have helped make Norway one of the world's wealthiest countries.

Geography-and our ability to make use of resources-is a dynamic concept. So is history.

Another 100 years have been added to Norway's maritime history. The 20 th century was a century of new opportunities, new policies, new lessons, new ideas and new strategies. It was also the century where shipping lost its dominant position in the Norwegian economy and in particular the hegemonial role in Norwegian exports. In the first 75 years of the 20th century, shipping revenue made up more than 43 per cent of Norwegian exports, in the last quarter of the century the share was less than 17 per cent.

At the start of the 20th century, shipping was an extremely important source of personal wealth, and this fact was also reflected in politics. Money was power, and well-off shipowners like Michelsen, Mowinckel and Knudsen played crucial roles in the birth and redefinition of Norway as a fully independent nation: "Shipowners held such an honourable position in the public opinion that they, almost as a matter of course, were expected to guide the national ship and bring the country and the people to a safe harbour." 1 Towards the end of the century, large private fortunes were primarily made in other sectors and statesmanlike Prime Ministers have been found elsewhere. Shipowners no longer make up such a large proportion of "the establishment" as before, and "the establishment" itself has lost part of its privilege and power. During the 20th century, shipping went from being extremely important to being "just" important. Still, a history of relative decline is also a history.

The 20th century brought a set of new heroes from the sea: the war sailors who kept supply lines open and risked — and lost - their lives for the Allied cause. The fact that it took decades for their crucial war efforts to be rewarded and acknowledged echoes the manner in which the sea and seafarers had previously been played down in Norwegian nationbuilding. There was a similar lack of recognition of the maritime dimension during the national romantic period in the 19th century, when

${ }^{1}$ Svendsen $(1976,7)$. 
Norway fought to develop its own national identity and throw off the shadows of Danish and Swedish rule. Inspired by the German traditions of von Herder, the archetypal Norwegian-the one inhabiting the spirit of the nation-was found inland, among peasants, in the forests and on the mountains, rather than along the coast. ${ }^{2}$

For many decades, the typical heroes of the Second World War were the domestic Norwegian resistance movement, often referred to as Gutta pa skauen - the boys from the woods. The prominence that they were awarded in most stories of the fight against the Nazis overshadowed the crucial role that Norwegian seafarers played in the outcome of the war. ${ }^{3}$ It also downplayed the sacrifices that the war sailors made-more than 3600 seafarers died as a result of the war, more than a third of all Norwegian deaths. A detailed academic history of the Norwegian war at sea was not written until the 1990s, while the war sailors had to wait another 20 years until the authorities apologized in public for the lack of recognition in the period after the war.

With the gradual removal of the shipping and seafaring dimension from the lives of most people, maritime history and maritime culture have become increasingly intertwined. Norwegians in the coastal areas continue to have a strong maritime identity, but it is typically related to forefathers that went to sea and old fortunes and artefacts, rather than to their own experiences. This detachment accelerated in the last part of the 20th century. As late as in the 1970s, around a third of all men in the Norwegian labour force had spent some time at sea-a fascinating figure that says something about the extent to which people's lives were influenced by the shipping sector and its opportunities. Thenabruptly - the development changed. The shipping crisis, and the policy shifts that followed in its wake, implied that seafaring became far less important, both as a temporary "rite of passage" and as a full-fledged career.

\footnotetext{
${ }^{2}$ Iversen $(2011,129)$.

${ }^{3}$ The common version of the war history even put particular emphasis on certain parts of the domestic resistance against the Nazis. Some factions of the resistance movement-for instance those illegal groups that had a Communist bent-were sometimes erased, or at least obscured, from the official history of the war. See Borgersrud and Eriksen $(2015,595)$, where the term "monopoly of information" is used about the non-Communist resistance.
} 
Norway, the shipping nation, continues to be relevant, although the number of Norwegian seafarers has shrunk and the ships people see and hear about are more likely to be offshore vessels or cruise vessels than cargo ships. ${ }^{4}$ The maritime culture changed gradually-first with the transformation from sail to steam, then, as the ships got larger; they became almost invisible, far removed from daily life. At the same time, the nostalgic element has shifted-the memories and the tales of the white sails have now been replaced by stories of young rookie sailors picking rust and experiencing exotic locations around the world.

In 1948, Karin Larsen, Professor of History at St. Olaf College in Minnesota, published a much-lauded book on the history of Norway. She pointed out that " $[t]$ hroughout Norway's history the greatest economic, political, and cultural advance has been achieved when the people have had untrammelled access to the surrounding ocean and have been able to make use of the opportunities this offers." ${ }^{5}$ When she wrote this claim, it turned out to have just as much relevance for the future-the second half of the 20th century — as for the past.

In the second half of the 20th century, new knowledge and new technologies enabled Norway to make use of opportunities that had been developing for thousands of years on the Norwegian sea bed. Exploitation of petroleum resources changed the economy, the politics and the culture. The maritime experience was extremely important for the formation of Norway as a petroleum producer. Shipowners, shipyards and seafarers all tried their luck in waters closer to home, then used the capabilities that they acquired there to expand abroad. Consequently, the manner in which these events unfolded was not unlike the expansion of Norwegian shipping in the 19th century: build up competence at home, and then compete in the world market.

\footnotetext{
${ }^{4} \mathrm{An}$ exception is along the West Coast of Norway, all the way up to the north, where seaborne transport is still important for the movement of both passengers and cargoes. However, in particular in the densely populated areas in the south-western part of the country, trucks perform a surprisingly large part of the cargo transport. In these areas, the Norwegian authorities have built ridiculously expensive bridges and tunnels in order to get a "Highway number two," more or less parallel with the one that nature had already constructed.
}

${ }^{5}$ Larsen $(1948,4)$. 


\section{A Maritime Nation (-ation, -ation, -ation, -ation)}

What characterized Norwegian shipping in the 20th century? What were the external and internal forces that shaped its development? Which resources - and which responses - enabled Norwegian shipping companies to keep their position among the most important providers of seaborne transport services?

This book has presented the main development traits, the different breaking points and eras. We have seen how the international economy provided the backdrop-the ups and downs of world trade, affected by business cycles and trade policies, resource endowments and global shifts in production technology. We have seen how the two world wars were states of emergency, where shipping became a crucial, but deadly dangerous, activity, with substantial losses of men and tonnage. At the same time, the wars also ushered in modernization of the fleet, and thus paved the way for long-term growth. We have seen how Norway developed economically, politically and socially_how a maritime career went from being month after month at sea to another "Nice day at the office?" job.

Merchant shipping, "has been, and remains, arguably the world's most international business," according to the leading maritime historian, Skip Fischer. ${ }^{6}$ In order to be successful in an industry with global competition, the domestic skill-set and strategies have to be aligned with the requirements of markets far from home. This is extremely difficult, but Norway has managed to do it with impressive consistency.

Initially, we asked the question, "Which factors-specific to Norway, either alone or in combination-can explain the country's leading role in international shipping throughout the 20th century?" Returning to that question, we can now conclude that Norway's successful navigation of the world's most global industry depended on a number of factors: globalization, liberalization, concentration, specialization and innovation. These specific developments can be linked to the four analytical arenas that were presented in Chap. 1: the international, the national, the

\footnotetext{
${ }^{6}$ Fischer $(2016,78)$.
} 
regional and the company perspective. Naturally, the manner and pace with which these factors have evolved have not been uniform across the century-there have been periods of slow change and periods of rapid change, and even periods of reversal.

\section{International Development: Globalization}

From an international perspective it is fairly unproblematic to explain the development of the shipping industry and the relative position of the Norwegian participants. All we need is the most basic instrument in the economists' toolbox - the concepts of demand and supply. By linking demand and supply to economic globalization - increased integration in the world economy, seen as growing flows of goods, services and factors of production-the symbiotic relationship between the world economy and Norwegian shipping is easy to identify.

The expansion of world trade-higher volumes, more countries, new commodities - led to a high and increasing demand for the seaborne transport services that Norwegian shipping companies could offer. Although there has not been a one-to-one relationship between the growth of world trade and the development of the shipping market, the correlation between the two is strong. The overall trend has been going in one direction-more trade, and more demand for seaborne transport. But for shipping, the most turbulent periods have been when development has deviated from this trend. The shipping business is especially interesting when demand for transport capacity grows faster or more slowly than the international economy in general.

From a Norwegian perspective, three peacetime periods were particularly important - two with positive, and one with negative connotations. The first period in which the international market developed positively from a Norwegian point of view was the interwar period, when Norway's share of the world fleet doubled-from around 3.3 per cent in 1919 to more than 7 per cent by 1939. 7 The collapse of world trade during the

\footnotetext{
${ }^{7}$ See Fig. 1.1. The data in this chapter primarily refer to figures and tables that have been presented previously, and the footnotes will point to the previously used material, rather than the original source.
} 
Great Depression was partly a monetary phenomenon, appearing much more violent because of falling prices, but in the interwar period trade grew at a slower pace than before the First World War. However, seaborne trade increased faster than trade in general, as a result of longer distances and the fact that ships spent more time sailing "in ballast." In fact, certain segments even grew rapidly. The Norwegian strategy was focused on the main growth segment, oil tanker transport. A combination of outsourcing of transport services, extremely strong volume growth and increased distances made this by far the most positive segment of the shipping market in an otherwise difficult period.

Following the large losses during the Second World War, Norwegian shipping increased its market share in the years after the hostilities ended. Massive growth in manufacturing production and trade led to a strong increase in the transport of raw materials. Consequently, the focus on bulk transport continued to serve Norwegians well in the 1950s and 1960 s - the heyday of modern Norwegian shipping. Crude oil transport continued to expand rapidly, and was complemented by strong growth in the seaborne trade of dry bulk goods such as coal and iron ore. The industrialization of Japan, a country with a shortage of natural resources and an abundance cheap labour, was a particularly strong influence on the demand for shipping. Subsequent national industrialization projects in Asia-first in the "tiger economies" and then in China towards the end of the century-have had a similar positive effect on shipping demand.

In the interwar period and the first post-war decades, Norwegian shipping companies performed better than most of their competitors, due to their investments in market segments that grew more rapidly than other parts of the shipping sector. In this period they made a lucky bet on the tanker development, which was followed up by more resources when the benefits of the strategy became evident. In the bulk and specialized markets, Norwegians could supplement their vast market knowledge and international network of contacts by economies of scale and innovations in vessel technology to remain competitive.

This strategy was favourable in a growing market, but became problematic after the demand for shipping collapsed. Following the oil price 
increases of the 1970s, Norwegians performed relatively badly, in a market where overall development was particularly negative. The trajectory had gone from outperforming a growing market, to underperforming in a market that was going down. The collapse of the crude oil trade was the most important factor behind the adverse Norwegian development. Many owners had put all their eggs in one basket, and that was the basket where the handle broke...

During the shipping depression of the 1970s and the 1980s, it took almost 15 years before the markets recovered. ${ }^{8}$ As a result of the severity of the downturn - in particular the fact that there were hardly any profits to be made for more than a decade-Norwegian shipping was not far from being eradicated. The strategies that had made Norwegian owners particularly successful when the market increased-economies of scale, frequent tonnage renewal, a focus on bulk transport-made them particularly vulnerable when the market crashed.

Expensive investments in redundant tonnage led to high capital costs, and Norwegian labour costs were also high in an international perspective. With low freight revenues - or even no income at all, in the case of laid-up ships - the equity of many Norwegian shipping companies was rapidly depleted. Some survived due to the generosity of creditors, who waited patiently until the market recovered. Others were forced to approach the Norwegian authorities for support. By the beginning of 1979 the crisis had been such a drain on resources that more than half of the shipping companies had negative equity. ${ }^{9}$ And the crisis was far from over.

As the financial problems dragged on, and the creditors and the authorities ran out of patience, two of the avenues for survival were closed, with dramatic results. Banks forced the sale of ships. The authorities wound up their engagements in the Guarantee Institute, which at its peak had helped the owners of around a quarter of the fleet. The results were dire. The majority of the Norwegian shipping companies that existed in 1973 were out of business by 1987. Despite the most

\footnotetext{
${ }^{8}$ There was a brief recovery — a false dawn — around the turn of the decade. Optimistic shipowners reacted by ordering more tonnage, even before the existing surplus had been absorbed. The bad times consequently came back with a vengeance.

${ }^{9}$ Norway, Parliament (1980), Norges Offentlige Utredninger 45, 35.
} 
far-reaching support to the shipping sector ever, the authorities had only been able to put a plaster over what turned out to be a life-threatening wound.

Most of the shipping companies that survived the crisis were in a precarious financial situation. They were floating aimlessly, in choppy waters, and were about to sink when they were thrown two lifelines at the same time. The first one came from the market itself, where demand picked up and the removal of surplus tonnage ensured that freight rates followed suit. The second lifeline came from the Norwegian authorities. They introduced the Norwegian International Ship Register, thus enabling the use of low-cost foreign seafarers on Norwegian-flagged ships.

This takes us to the complementary, flipside explanation of the manner in which globalization influenced the development of Norwegian shipping. Globalization of demand was strong throughout the period after the Second World War, and increasing international trade was the fundamental precondition behind the growth of the world fleet. The last decades of the century also saw the globalization of supply. ${ }^{10}$ Increasing international integration has given better access to capital and labour outside Norway's borders. However, the degree to which shipowners have been able to utilize foreign inputs has varied.

With regard to capital, access to foreign funding has in fact been important since before the Second World War. The interwar growth in the tanker market was partly financed by Danish, Swedish and British yard credits, thus enabling an expansion that would have been impossible if it had been drawn from Norwegian sources only. What was originally a cyclical phenomenon - access to finance in order to secure shipyard activity during a downturn — ended up as a permanent phenomenon, a competitive parameter for shipbuilders. In the post-war period 80 per cent credit at generous terms became the norm for shipping companies that wanted to buy new tonnage. The shipyards, helped financially by the authorities, ensured much of the financing. Consequently, the expansion of the fleet could to some extent occur independently of Norway's own

\footnotetext{
${ }^{10}$ Even though the tanker market crashed due to the oil shocks, globalization-in terms of increasing international integration, in particular trade liberalization and growth-remained the order of the day in most other markets.
} 
financial resources. Most of the costs of a new ship could be acquired abroad, often with a long-term charter securing the income and consoling the creditors. Second-priority mortgages could be arranged by government-supported Norwegian institutions.

Due to other governments' desire to build up or maintain capacity in the shipbuilding industry, foreign loans financed much of the expansion of Norwegian shipping. Foreign equity, on the other hand, has been limited by Norwegian law for much of the century. Even in the late 1980s, shipping companies that wanted to increase their funds by opening up share ownership to foreign interests had to issue non-voting B-shares. By then, foreign funds were accepted, but not foreign influence. This was soon to change.

In the last years of the 20th century, and particularly at the beginning of the 21st century, there was a strong inflow of foreign equity into Norwegian shipping. There were two main reasons for this. First, the liberalization of international capital movements made it difficult, or in some instances even illegal, to discriminate against foreign owners. The Norwegian authorities were forced to open up the borders, and could no longer reserve ownership and influence for Norwegians. Second, the strong market position, the international character and the competitive competence of Norwegian shipping companies made them particularly attractive for mergers and takeovers. Foreign equity flowed into Norway in search of profit, and Norwegian equity went abroad in search of the same. ${ }^{11}$

The access to foreign investment capital (as opposed to foreign mortgages) was limited for most of the 20th century, before this regime change. This corresponds very well with the situation for foreign labour. For a long time, Norwegian shipping was based almost exclusively on Norwegian personnel. During the labour shortages in the 1950s and 1960 s, seafarers from other European countries played a part, and there were also some foreign-crewed ships operating in local markets in Asia.

\footnotetext{
${ }^{11}$ And sometimes Norwegian investors went abroad, only to return to the Norwegian market under more tax-friendly foreign schemes. Klepsland $(2011,3)$ points out that before 2003 active foreign ownership in stock exchange listed Norwegian shipping companies was related to acquisitions and delisting, while the foreign ownership from 2003 to 2007 was characterized by "Norwegian tax refugees."
} 
Still, the rule-of-thumb was Norwegian ship, Norwegian flag, Norwegian seafarers-or European seafarers on Norwegian terms-well into the 1980s. The big shift came in 1987, when the establishment of the Norwegian International Ship Register (NIS) lifted restrictions for ships that operated outside Norwegian waters.

\section{The Domestic Dimension: Liberalization}

The establishment of the NIS is perhaps the best example of how the domestic dimension has been characterized by significant liberalization of the maritime-political regime. The increasing inflow of foreign equity changed Norwegian shipping; access to inexpensive foreign labour saved it. Norway's transition to a high-wage country-where seafarers' working conditions improved immensely during the course of the century-was incompatible with the relentless focus on costs in an industry with international competition. The liberalization of labour requirements was a necessary condition for the "second wind" that pushed Norway's shipping industry forward in the last decades of the 20th century. Without this measure, it is likely that many of the remaining Norwegian shipping companies would have followed their Swedish neighbours into obscurity and oblivion, and the establishment of new companies would have been much lower. ${ }^{12}$

Despite this timely intervention by the Norwegian government, the relationship between the shipping companies and the authorities has been very complex. The design of the economic and political regime has varied across time, and the effects on shipping company strategy and profitability are difficult to disentangle. Many shipowners would claim that the regulation of the industry, in particular in the period around 1950, was a serious encroachment on their free enterprise and had a detrimental effect on the expansion of their shipping activities. The detailed regulation of business decisions such as contracting, operation and financing has been referred to as a "straitjacket."13

\footnotetext{
${ }^{12}$ Lennerfors, Lindgren and Poulsen (2012).

${ }^{13}$ Bakka (2017).
} 
At the same time, it is evident that the Norwegian authorities have also given the shipping industry priority, due to its role as the most important earner of foreign exchange. This has been evident with regard to explicitly preferential measures - such as access to investment funds and generous accounting and tax rules. There have also been periods-for instance in the 1950s and 1960s - when the general economic policy favoured shipping investments. Regulations such as double taxation-which made it profitable to maintain capital within the company-and the low interestrate regime had a preserving character on the industrial structure. Access to funds was easy for established companies, while it was difficult for newcomers. And shipping was clearly an established industry.

The international character of shipping makes regulation, both policy design and policy implementation, particularly difficult. On the one hand, it might be desirable to treat shipping in the same way as other domestic sectors. This ideal of "industrial neutrality" implies that tax rates, investment framework (for instance duties and depreciation rates), access to capital and so on should be identical across all sectors of the economy. The benefit would be that the country's resources-at least in theory — would be utilized efficiently, as they would be allocated to those sectors that give the highest return, without any policy-induced distortions.

Alternatively, it might be claimed that policies should be adapted to the special features and needs of individual sectors, and also take into account policy aims other than just "economic efficiency." The support to the agricultural sector in most industrialized countries - motivated by a desire for self-sufficiency in food production, a heavy dose of nostalgia and some very capable lobbying - is a case in point. When everyone else is subsidizing, why can't we? According to this view, policies towards the shipping sector should, due to shipping's mobile nature, be designed with "competitive neutrality" in mind. How can we keep taxing our shipping companies, when they can easily move their activities to a no-tax location? Following this line of thought, the framework conditions should be identical to those that the shipping industries in other countries are subject to.

Norwegian policy has vacillated between these two aims-between industrial neutrality and competitive neutrality. Moreover, when the 
shipping industry has been subject to "special treatment" this has been both of the favourable and the unfavourable kind, with the changes often abrupt and unexplained. As such, the influence of shipping policy has been unpredictable. For instance, in the immediate post-war years, shipping was given priority in the access to foreign exchange- the aim was to resurrect the industry and its dominant position as a foreign-exchange earner. When the revenues failed to materialize to the extent that had been hoped for-mainly as a result of inferior tonnage and low freight rates - the authorities introduced a ban on contracting abroad in 1949 and 1950.

Greek owners copied the timecharter-based financing that the Norwegians had pioneered in the interwar period and "exploited the gap created in the tanker market by the hitherto dominant Norwegians." 14 The gap in the market was the direct result of the political restrictions on the ordering of new ships abroad. Norwegians had to say "no" to lucrative tanker contracts and were unable to fully take advantage of the boom during the Korean War. Preference was followed by prohibition. Go was followed by stop.

Political measures such as the contracting ban had an immediate and direct effect on Norwegian shipping companies and their competitiveness. In the longer term, however, the indirect effects have been more important. The overall policy regime, in addition to the specific short-term measures, has influenced the business decisions of shipping companies. One example is how the combination of tax policy and labour regulations, in a pincer-like movement, shaped the "economies of scale"-based investment strategy in the 1960s. As a result of this focus on large ships and the frequent fleet renewal, the Norwegian share of the world fleet peaked around 10 per cent in the late 1960s.

Until the crisis in the 1970s, shipping's important role in the Norwegian economy was sufficient to ensure its position in the Norwegian political landscape. There was a joint understanding that the shipping industry was left to its own devices. When the crisis threatened the viability of the

${ }^{14}$ Harlaftis and Theotokas (2009, 20). 
sector, the policies changed "from benign neglect to government intervention." 15 Two important political measures were introduced.

- First, the Guarantee Institute for Ships and Drilling Vessels (GI) was established in 1975 to avoid ships being sold abroad due to bankruptcies and creditor demands. It is not evident that the shipping companies were the main beneficiaries of the GI-the authorities had ulterior motives, and the establishment was important both for shipyards and the financial sector. The GI had the desired short-term effects-it succeeded in keeping tonnage in Norway-but in reality it only delayed an inevitable decline in the fleet.

- The second political change had important long-term effects. As mentioned above, the introduction of the NIS ensured that the Norwegian shipping companies could regain their competitiveness. With the increasingly cut-throat competition in the shipping market, and with freight rate levels too low to give investments in labour-saving tonnage, the only viable alternatives were sales to foreigners and transfers to Flags of Convenience. The introduction of the NIS combined the labour cost flexibility of the Flags of Convenience with a continued "genuine link" to Norway. Moreover, by limiting the areas in which the ships could trade, shipping along the coast remained a domain for Norwegian seafarers.

Norway's introduction of a second or open register was followed by similar measures in other countries. It was both a response to and an element in the liberalization of shipping at the international level. It was another step in the constitution of shipping as the most global of industries. The liberalization of the shipping regime was not unique in a domestic context either. Indeed, it should be seen in relation to the liberalization of the Norwegian economy and society in general. The important thing is the end result, though: without deregulation, Norwegian shipping would not have been able to maintain market shares and profitability.

${ }^{15}$ Nordvik (1997). 


\section{The Regional Dimension: Concentration and Specialization}

The regional dimension has seen Norwegian shipping develop from an industry scattered all along the coast, to a higher degree of concentration, with Oslo and Bergen as the leading centres. There has also been an evident concentration of other maritime activities in these two major cities, although with some more isolated pockets of activity in other places. The other development trend that has characterized the spatial distribution of Norwegian shipping is specialization, the manner in which a functional division of labour has developed among Norway's regions.

Norwegian shipping survived as an economic activity along the coast far longer than in neighbouring countries such as Sweden and Denmark. In Denmark, in particular, the shipping industry in the capital largely overshadowed what was going on in other parts of the country. ${ }^{16}$ However, the large reduction in the number of shipping companies as a result of the shipping crisis sounded the death knell for a number of home ports along the coast.

The increased concentration of Norwegian shipping was also reflected in policy-making and political lobbying. Two developments in the 1980s implied that the industry's economic importance was no longer as selfevident as it had previously been. First, shipping's dominant role as a foreign exchange earner had been dethroned by the petroleum sector. Second, Norwegian sailors in the deep-sea fleet were replaced by foreigners. As a result of the industry's reduced standing, the Norwegian Shipowners' Association changed its strategy vis-à-vis the authorities. It increasingly emphasized the crucial role that shipping companies played as the hub of a "maritime cluster," where other maritime businesseswithin finance, insurance, ship equipment, classification and so onwere involved. The economic health of the shipping companies was important for the strength of the cluster.

\footnotetext{
${ }^{16}$ The development of the offshore oil industry brought some decentralization in Denmark as well, with Esbjerg emerging as the most important harbour for the oil industry, and with offshore wind power emerging as another important business area in the new millennium.
} 
With regard to the regional dimension, there have been two contrasting ownership trends. On the one hand, we have seen an overall development towards concentration: by the end of the 20th century around half the fleet, measured by dead weight tonnage, was owned by shipping companies in Oslo, and almost a quarter by Bergen-based shipping companies. On the other hand, in connection with the expansion of the offshore petroleum industry, the related services have to a large extent been based in the Stavanger region, as well as in a number of relatively small locations along the coast—villages and islands that had not usually featured in the list of home ports for the Norwegian foreign-going fleet. In places such as Austevoll, Bømlo and Fosnavåg — small communities with a fishing, rather than a shipping tradition-resourceful owners entered the supply shipping industry. In some cases they expanded by purchasing second-hand ships from larger shipping companies that had decided to exit the segment. The conditions in the North Sea are extremely rough, and the companies were able to use the competence built up in Norwegian waters to expand internationally.

In 1900 Norwegian shipping could be characterized as a relative uniform industry - with significant regional variations primarily along one dimension: the extent to which the transformation from sail to steam had progressed. There have been various degrees of specialization in different parts of Norway. Strategies based on new technology, new forms of operation and specific market niches enabled Norwegian shipping companies to carve out profitable niches. The different trajectories that characterized the development of the various regions pay some testament to the idea of maritime clusters. These clusters could be based on beneficial (or dangerous) follow-thy-neighbour groupthink, or on the synergy effects of having a number of competitors within the same market segment.

The specialization was evident in the case of Oslo and Bergen. In Oslo, the activity was based on traditional bulk activities, with substantial players in the dry bulk and crude oil markets, as well as a number of diversified companies. Bergen, on the other hand, became the "industrial shipping capital," where long-term customer relations had built up world-class niche companies. The city housed two of the world's leading chemical tanker operators, Odfjell and JO Tankers. It was also the origi- 
nal home of the two companies that dominated the world market for open-hatch bulk transport, Star Shipping and Gearbulk. They had a joint market share of around 60 per cent, while Saga Forest Carriers, the third largest operator, also had close links to Norway.

Gearbulk and Saga Forest Carriers are good illustrations of the increased internationalization of Norwegian shipping. The entrepreneur behind Gearbulk, Kristian Gerhard Jebsen, sold 40 per cent of the company to the Japanese Mitsui OSK Lines in 1990, and moved the operation of the company to the UK a few years later. He still had much shipping activity in Bergen, and used his hometown as the basis for investments in other segments. Saga Forest Carriers, on the other hand, had originally grown out of a Norwegian pool based in the eastern part of the country, but was in 1995 taken over by the Japanese company Nippon Yushen Kaisha (NYK). The Japanese decided to maintain accounting and management with the company Hesnes Shipping, a specialized shipbroker based near Tønsberg.

The concentration of the shipping industry at the geographical level reflected the success — or lack of such — of shipping companies in various Norwegian regions, as well as the relocation of companies. It might seem paradoxical that parallel with the reduced cost of communication, shipping companies tended to be located more closely together, and closer to auxiliary services such as insurance and banking. In 1900-when communication was difficult - they were spread all along the coast. A century later-when communication was uncomplicated and the whole world was just an e-mail or a phone-call away-they tended to be lumped together in Oslo or Bergen.

\section{Business Development: Professionalization and Innovation}

The location paradox above may perhaps be explained by the manner in which the competitive advantage has changed. As a result of technological and regulatory developments, the amount of information available, and the need for documentation, has become more plentiful. This has led to a professionalization of Norwegian shipping. Separation of ownership 
and management and bureaucratic organizations with a functional division of labour characterize the leading Norwegian shipping companies.

The competitive advantage has changed from local knowledge-in the port - to centralized knowledge — at the company's headquarters. It has changed from personal competence-the captain and crew at sea and the shipowner onshore-to organizational competence-the many divisions of the shipping company, each with a specific role and designated tasks. The days where Ragnar Moltzau could operate his own little tanker shipping company from the corner of the office he shared with his employer are over. ${ }^{17}$ Shipping today is characterized by vetting, governance and compliance; by throughput, integrated logistics solutions, documentation and due diligence.

As communications improved, having excellent ship captains became less of a competitive advantage, as more and more of the business decisions were made at the company's headquarters. However, this does not imply that competence on the ship became irrelevant. Captains had to organize work on board and in port as efficiently as possible, they had to strike the right balance between overseer and officer. They still had important knowledge about the crew, the ships and the ports. Moreover, captains often went onshore, temporarily or permanently, to work as building supervisors or port captains, or to perform other important tasks.

Shipowners and shipping companies had to be able to optimize the business model and choose the right strategies. They had to be able to source cost-efficient inputs—ships, capital, labour-and to identify and target the markets where they could make a profit. Again, we have to remember that there was not one Norwegian strategy or policy, and many shipping companies failed on both counts-high costs led to uncompetitive production, and a focus on wrong markets led to low, or non-existent, revenues.

One feature that ensured the competitiveness of Norwegian shipping was innovation. This took place at two levels - technological and organizational. The technological dimension refers to the manner in which shipping companies managed to strengthen their competitive position by means of investments that alleviated their comparative disadvantages.

${ }^{17}$ See Fasting (1955). 
Sometimes the owners played a key role in the development of the new technologies, other times they imitated, and sometimes they failed to invest—or refrained from investing —in the "winning" technologies.

In the post-war period, in particular, technological innovation enabled Norwegian shipping companies to gain market shares and operate profitably. The establishment and expansion of specialized shipping nichesgas and chemical tankers, cruise ships, vehicle carriers, open-hatch bulk ships-provided periods of substantial market power and large profits. Moreover, when the dry and liquid bulk markets were characterized by a structural crisis in the 1970s and 1980s, the niches were relatively well-functioning.

Organizational innovation is an umbrella that covers various new ways of "doing shipping"; operational innovation, institutional innovation, financial innovation and so on It includes new ways of organizing the companies-from regional part ownerships to stock exchange listed entities with owners from all over the world. It includes new types of business relations - the long-term charters with the oil companies in the interwar period naturally spring to mind. It includes new ways of raising capitalthe use of shipyard credits, limited partnerships and incomprehensible financial instruments. It includes new ways of operation and management-outsourcing of parts of the business, joint partnerships and cooperation in pools. And, importantly, organizational innovation includes new ways of relating to the rest of the world-foreign seafarers, foreign flags, foreign investors, foreign partners. One of the defining development trends in shipping is the manner in which resources can be sourced where they are most cost-efficient. This implies that the Norwegian dimension becomes obscured, as more and more transactions have a foreign base and large parts of the business can be outsourced.

The manner in which shipping companies managed to deal with these two parameters - professionalization and innovation-was important in determining whether they became successes or failures. The transformation of Norwegian shipping in the 20th century saw a massive turnover in the agents of the industry. At the company level, survival was the exception, not the rule. At the same time, when we look at Norwegian shipping in general, the industry has shown exceptional resilience. Even today, we find a two-digit number of companies that have been involved 
in shipping for a century or more. However, the majority of the companies have a much shorter history. Some have been established on the ruins of failed companies, others have seen new opportunities. Some will remain competitive, others will fail.

\section{Still a Shipping Nation?}

Norwegian shipping companies gained their leading position in shipping by chasing international demand all over the world in the second half of the 19th century. They have maintained their leading position by utilizing international supply - global factors of production-in the last part of the 20th century. With most of the employment and parts of the ownership and management located elsewhere, is Norway still a shipping nation? Are Norwegians still shipowners?

In order to answer this question, it may be useful to draw a parallel to another old industry-farming. Previously, the farmer and his family often did "everything" themselves; worked in the field, tended the animals in the barn and sold their produce at the local market. Gradually, as technology and infrastructure improved, farm sizes increased, farmers specialized and machines and hired hands took over much of the manual work. Many of the farmers today are managers and administratorssome do not even have dirt on their boots. They may spend most of the day indoors, shifting papers around. But they still own and develop their main asset - the farm-and make the decisions that ultimately decide whether this business is viable or not. It is very clear, that "the old way" would not be a viable manner in which to conduct farming business. ${ }^{18}$

The business of Norwegian shipping companies is much the same. More than a century ago, time ran out for the old part ownership, with a strong community foundation and a base of local labour and capital.

\footnotetext{
${ }^{18}$ Some farmers might today receive a higher price for growing in an old-fashioned manner, selling the produce with a "bio-dynamic" or "organic" premium, while others supplement their incomes by farm visits. Although such ventures might be profitable on an individual basis, for the sector as a whole, this is not a viable strategy. The shipping equivalent would be the larger sailing ships offering shorter voyages to a moneyed clientele that wants to experience a pleasurable and sugar-coated version of the days of the windjammers.
} 
Gradually, more and more of the inputs were acquired further and further away from home. The local inputs became national, then the national inputs became international. Still, the core of the business - the decisions that give profits or losses_-and a substantial part of the ownership remains within Norway. There is also an infrastructure-for financing, insurance, broking and so on-which supports these decisions, and which also has a strong local component.

In the 20th century the Norwegian shipping industry-seafarers, investors, managers-experienced enormous amounts of drama and change. Both world wars presented challenges, even though the status of the fleet was very different. Norwegian shipping companies grasped new opportunities in the interwar period and during the post-war boom. They had to fight to remain floating during the shipping crisis of the 1970s and 1980s. The introduction of the NIS, fortuitously coinciding with the rebound of the market, gave them a fresh start. Throughout the century, everyone working for Norwegian shipping has been tested again and again.

Consequently, the actual development provides us with a real-world evaluation of how well they succeeded. The grade transcript clearly shows that Norwegian shipping passed, and passed with honours. For the shipping industry as a whole, there must have been more successes than failures. Without a steady influx of successful newcomers that could replace the ones that were punished by the market forces for their bad decisions, the industry would have disappeared-like it did in so many other European countries. Norway started and finished the 20th century as one of the world's leading shipping nations, though the basis for the position had changed tremendously.

\section{Early 21st Century Blues: Taxing Times}

Norwegian shipping companies owned between 4 and 5 per cent of the world fleet at the start of the 20th century and more than 8 per cent at the end of it. Along the way, the share varied substantially: it was particularly low after the two world wars, and peaked at around 10 per cent in the late 1960s. In the first half of the 1980s, the fleet appeared to be 
disappearing, before an improving market and domestic institutional innovation enabled an impressive rebound.

The fleet's development during the 20th century was far more positive than what its most important competitors experienced. The dominant shipping nation in 1900 - the UK-fell from around half of the world fleet to less than 3 per cent, Germany saw its 9 per cent share more than halved, while the United States fell from more than 8 to less than 6 per cent. ${ }^{19}$ Norway had apparently escaped the loss of competitiveness that had befallen its main competitors.

However, if we update the end point, the picture is not as clear. If we terminate the analysis in 2017, rather than at the end of the 20th century, the Norwegian success story becomes less convincing, it is less of a success story. By 2017 Norway had fallen from third to ninth place on the list of the world's leading ship-owning nations. The proportion of the world fleet had fallen from more than 8 to around 2.8 per cent. In other words, over this brief period-less than two decades - the Norwegian market share declined more than Germany's had done throughout the 20th century.

One of the reasons for the decline was the fact that some of the largest and most successful shipping companies were taken over by foreigners. The national consolidation processes in the 1990s were just the first step. These were then engulfed by an international wave of mergers and acquisitions. In many instances the Norwegian shipping companies were attractive targets. Sig. Bergesen dy had taken over the fleets of two other companies to become one of the leading international companies in the gas carrier market, and also had a substantial tanker fleet. In 2003 the company-whose fleet amounted to more than 10 million dead weight tons, making up slightly more than 20 per cent of the Norwegian fleetwas sold to Hong Kong interests. Although some parts of the operation continued from Norway, the jewel in the crown was gone.

The first years of the new millennium were characterized by sales of tonnage abroad. In contrast to the sales in the 1980s, the ships were not sold because the companies had problems. The ships and the companies

\footnotetext{
${ }^{19}$ Confer Tables 2.1 and 9.1 for details on the data. Percentages measured as share of effective tonnage in 1900 and dead weight tonnage in 2001.
} 
were sold because they were attractive to foreign investors. This period was also marked by substantial turbulence among the companies that remained, in particular in their relationship with the authorities. The basis for the animosity was a well-known topic: tax.

The dogfight about tax marked a low point in the relationship between the authorities and the shipping companies-mistrust of a kind that had not been seen since the restrictions on foreign contracting in the late 1940s and early 1950s. The basis was the transfer to a tonnage tax regime in line with most European Union countries. In principle, the introduction of a beneficial tax system should have been welcomed by Norwegian shipowners. However, they believed that they already operated in a benign tax regime, and had done so since the last major reform, in 1996.

They were wrong. The small print revealed that the 1996 system only deferred tax payments, it did not abolish them. In 2005 the government revealed how it would "harmonize" the tax system with other European countries; this would be done by introducing a new tonnage tax regime. Somewhat surprisingly, those companies that wanted to be included in the new regime had to pay the accrued (and deferred) taxes for all the years after 1996.

The tax bill was enormous-NOK 21 billion, of which two-thirds should be paid and one-third could be "written off" in exchange for environmentally friendly investments. The retrospective taxation also had some truly bizarre effects. In 2007-one of the best years ever for shipping, when an iron- and coal-hungry China drove up bulk rates-many Norwegian shipping companies reported enormous after-tax losses. Two years later, part of the tax payments was reversed following a Supreme Court decision that ruled out the claim for backdated taxes. In a shipping market that had gone from red hot to decidedly chilly, Norwegian shipping companies could post quite impressive results. ${ }^{20}$

It was not only the relationship with the Norwegian authorities that was strained. In addition to the trouble on the home front, a number of

\footnotetext{
${ }^{20}$ An example is Bergen-based Kristian Gerhard Jebsen Skipsrederi AS, which in 2007, when the latent payment was activated, paid a tax bill of more than USD200 million. When added to financial costs, this turned an operating surplus of USD211 million into a deficit. In 2009, the repatriation of USD120 million, following the Supreme Court ruling, gave the company one of its best results ever in a generally dismal year; see Tenold (2015, 298-299).
} 
shipping companies ended up in trouble abroad. One of the Norwegian success stories of the late 20th century was how companies had managed to build up dominant positions in niche markets. Now some of these companies were targeted by the competition authorities and accused of anticompetitive practices.

In a series of dawn raids in February 2003, the competition authorities, in cooperation with the EFTA Surveillance Authority, visited the offices of the world's leading chemical tanker operators. The Bergen shipping companies Odfjell ASA and JO Tankers were among four companies that were in trouble with the US competition authorities. Accused of colluding to keep freight rates high in the chemical tanker market, the companies agreed to pay substantial settlements to the US authorities and major customers. Stolt-Nielsen, another company with Norwegian roots, was given an amnesty in the case, claiming "whistle-blower" status. Still, for the involved companies the total costs, including legal fees, amounted to hundreds of millions of dollars.

Around 10 years later there were new raids. In September 2012, the European competition authorities, working together with colleagues in Japan and the United States, raided the offices of several car carrier companies. The companies, including Wallenius Wilhelmsen Logistics and EUKOR, subsidiaries of Wilh. Wilhelmsen ASA, were accused of keeping rates in their segment artificially high. So far, the companies have paid penalties for price-fixing, bid-rigging or related practices in, among other countries, Japan, China, the United States, Korea and the European Union. ${ }^{21}$

The two cases above show that Norwegian shipping companies still played an important role in the international market, although the declining Norwegian share of the world fleet in the period 2000-2017 reveals a substantially reduced position in the world fleet per se. There are primarily three factors that can explain the decline, and all of these suggest that the notion of a much weakened Norwegian shipping industry should be nuanced.

The first is the aforementioned sales of all or part of Norwegian shipping companies to foreign owners. In many instances important activities

${ }^{21}$ Wallenius Wilhelmsen, Annual Report, various issues. 
remained in Norway, even though the ownership changed. In other cases there were substantial underreported Norwegian ownership interests in companies abroad. Due to the difficulties of determining the "nationality" of ships and shipping companies, the statistics leave a lot to be desired. There is no doubt that there was a reduction in Norwegian ownership as companies were sold out. However, the statistics tend to overestimate the effects. The more than two percentage points decline in the Norwegian share from 2003 to 2005 was to a large extent related to the fact that the Bergesen group and Navion were sold to foreign interests. However, activity at the companies' headquarters in Oslo and Stavanger was practically unchanged in the short term.

The second reason that the decline has to be nuanced is the manner in which the world fleet increased. After 2000 the world fleet has gone through its most rapid growth period ever, while the size of the Norwegian fleet has practically been standing still-hence the reduced share. However, a large proportion of the new tonnage was relatively simple vessels. In particular, in the period 2005-2010 there was a flood of bulk carriers built to satisfy China's almost insatiable appetite for iron ore. Although some Norwegian shipping companies were involved in this expansion, the main investors were found elsewhere.

The difference to the boom at the beginning of the 1970s is striking. In 1974, Norwegian shipping companies owned around 9 per cent of the world fleet, but held almost 13.5 per cent of the newbuilding orders. ${ }^{22}$ Thirty years later, they owned around 5 per cent of the world fleet, but were responsible for only 3 per cent of the new orders. ${ }^{23}$ This was partly a reflection of the fact that Norwegians refrained from investing in ships that weigh heavy in tonnage terms - the simple large tankers and dry bulk carriers-but continued to buy ships that were technologically advanced and had a high value per ton.

This brings us to the final reason, where the price per ton is taken to the extreme: the Norwegian investments in offshore. In the year 2000, the offshore vessels made up the most valuable part of the Norwegian fleet, and these hardly count at all if the market share is calculated on the

\footnotetext{
${ }^{22}$ Calculated on the basis of Fearnley \& Egers Chartering Co, Review 1974.

${ }^{23}$ Aftenposten, 11012005, 5.
} 
basis of gross tonnage or dead weight tonnage. The declining Norwegian share of the world fleet at the beginning of the 21 st century is a continuation of the trend that characterized the last part of the 20th century. As we saw in the last chapter, this echoes the apparent stagnation in the Norwegian fleet at the end of the 19th century. When we take into account the properties of the tonnage - a shift from sail to steam, or from large simple ships to small specialized vessels - the stagnation becomes a statistical artefact, not reflecting the realities.

If we consider the value of the fleet, rather than tonnage figures, Norway was sixth in the world in 2015, even at a time when the value of offshore vessels was depressed. Although there had been little or no growth in tonnage terms, the value of the Norwegian fleet had more than doubled after the year 2000. Still, with the rapid growth of the world fleet, this doubling of the value was insufficient to maintain the international share. However, the relative decline in value was much less dramatic than the decline in tonnage terms.

The transformation of the activities is reflected in the fact that Norway owned 16 per cent of the world offshore fleet, by value, substantially more than for most other segments. In a recent report, the Norwegian Shipowners' Association excludes the three largest tonnage groups-dry bulk vessels, tankers and container ships. By focusing on the advanced part of the world merchant marine, Norway in fact comes out on top, owning the world's most valuable fleet. ${ }^{24}$ In 2013-2014 offshore vessels made up almost half of the value of this fleet.

A similar shift towards offshore is evident if we look at employment in the Norwegian maritime sector. From 2004 to 2014, the traditional shipping companies, those involved in deep-sea shipping, had a reduction in the number of employees of more than 4000 . This was a result of the movement of companies and functions abroad. Some of the foreign interests that had bought Norwegian companies relocated all or part of their activities. Moreover, many Norwegian-owned companies also began a process where operations, management, technical services and so on were outsourced internationally. The offshore shipping companies, on

\footnotetext{
${ }^{24}$ Norges Rederiforbund $(2015,8)$. Creative ways of counting are something of a Norwegian specialty.
} 
the other hand, increased the number of employees by more than 8000 , giving a net increase in the number of persons employed in shipping companies. $^{25}$

The development in the first decades of the 21 st century has also seen regional displacement. Activities in the two main shipping centres have developed very differently; "while traditional shipping has gradually been built down, moved out or changed in a financial direction in Oslo, Bergen has been able to maintain its position as a shipping city." By 2015 the tonnage registered in Bergen made up more than 40 per cent of the Norwegian fleet, and the city's fleet was more than one-third larger than the Oslo fleet. Expansion in old companies and a set of active newcomers in Bergen, combined with a decline in the fleet registered in the capital, can explain why the two have traded places at the top of Norwegian shipping in the first decades of the 20 th century. ${ }^{26}$ Moreover, overinvestment in the offshore sector, followed by a rate drop and a dramatic decline in the value of the vessels, created a need for restructuring. This consolidation process has increased the concentration in that part of the shipping industry, both company- and location-wise.

\section{Is There a Future for Norwegian Shipping in the 21st Century?}

People in northern Europe are known for having a relatively worried attitude to life; the glass is usually half empty, seldom half full. In Norway, the question of "How can we make a living when the oil in the North Sea runs out?" has preoccupied the population and the authorities for decades. Two insights from the analysis in this book might provide some help in answering this question.

First, by adapting strategies and policies, it is possible to remain competitive in an international market, even for a country with a high income level. Shipping did this for most of the 20th century, changing investment

\footnotetext{
${ }^{25}$ Menon $(2017,11)$.

${ }^{26}$ Menon $(2017,86)$.
} 
strategies and the regulatory framework to be able to utilize competitive advantages.

The offshore oil exploration in the North Sea has enabled the accumulation of a vast body of competence, and this can be employed elsewhere. The export of offshore services has already begun on a large scale. Norwegian companies operating offshore vessels get around 60 per cent of their revenue from ships working outside the Norwegian sector, and 40 per cent from Norwegian waters. ${ }^{27}$

The manner in which the offshore industry became internationalized had much in common with the manner in which Norwegian shipping grabbed global market share in the 19th century. It built up skills in a relatively protected home market, before venturing out to compete on the world stage. Norwegian shipping showed that it was possible to become a leading maritime nation without a big home market. Consequently, Norwegian oil industry participants-including the many companies involved in maritime activities_ _ can do the same when activity in the North Sea is reduced. ${ }^{28}$

Moreover, there is another similarity between the current offshore expansion and the shipping expansion after 1850. To a large extent, the activities are embedded in local communities, where the ship is built at local yards and much of the technology is provided by local producers. At the end of the 19th century, the shipbuilding industry in Norway encountered severe problems, as it was "stuck" in an old technological paradigm-wooden sailing ships-when steam and steel took over. Today, the Norwegian offshore yards are at the technological frontier. They have a leading position, both when it comes to the vessels that are manufactured and the manner in which they are built.

The second insight from the analysis is also related to the competitiveness of Norwegian shipping. Even before oil was found, Norway had a high standard of living and relatively balanced external economic relations. More than any other sector, shipping played a crucial role in this respect, neutralizing the deficit on the balance of trade. At the same time,

\footnotetext{
${ }^{27}$ Norges Rederiforbund $(2015,4)$.

${ }^{28}$ Of course, given what we know about climate and the environment, the long-term viability of a business model centred around petroleum exploration, even when freed from the limited Norwegian resources, can be debated.
} 
the manner in which Norway remained competitive, gradually eroded the country's advantages. Norwegian shipping maintained a large share of the international market for seaborne transport by becoming less Norwegian.

Foreign demand had been the main basis of Norwegian shipping ever since the late 19th century. Financing from abroad was important for much of the 20th century, but in the last decades two additional "international" elements were added. First, Norwegian deep-sea seafarers were replaced by foreigners. Second, foreign companies bought up Norwegian companies, both the hardware- the ships-and the software- the knowledge.

Due to the international character of shipping, Norwegian companies argue that they need "a level playing field" - that the rules of the game should be identical to their competitors. The result has been a beneficial tax regime, an international ship register, competitive labour conditions and so on. However, as the conditions become more equal, it becomes much more difficult to build national distinction, much more difficult to stand out. Current shipping industry buzzwords such as "digitalization" and "big data" will most likely contribute further to this trend.

When every shipping company has access to the same information, which competitive parameters can the Norwegian shipping industry rely on? When labour and capital is drawn from a global pool, why should it choose Norwegian ships and Norwegian companies? When registration costs and tax conditions are practically identical in most countries, why choose Norway?

We can go back to the beginning of this chapter, where we repeated the question about Norwegian shipping, about its role and about its basis. We can then "fast forward" the question 100 years. The reformulated problem is then: "Which factors-specific to Norway, either alone or in combination-can ensure that the country maintains a leading role in international shipping in the 21 st century?"

Although it is impossible to answer this question, it might be worth trying to identify some of the critical issues. Three factors make Norway stand out in an international perspective, even in the "practically all things equal" world of shipping. First, the country has a broad and highskilled maritime milieu, and sea-related activities make up a very large 
share of the economy. Second, Norway has long maritime traditions, and there is still a maritime identity and awareness that is lacking in many other countries. Third, Norway is a high-income economy, but one with an egalitarian culture and a compressed wage structure.

The first Norwegian advantage is the broad maritime milieu. The shipping companies have been at the centre of a business cluster that included shipbuilders and manufacturers of maritime equipment, in addition to a wide range of service industries - shipbrokers, classification agencies, naval architects, insurance companies and banks. Gradually, the frontiers of this cluster have become fuzzier.

Just like when the term "shipping policy" was replaced by "maritime policy" in the 1990s, the maritime dimension keeps growing. The Ministry of Trade, Industry and Fisheries in 2015 launched a comprehensive maritime strategy, where it uses the term "the ocean-based industries." ${ }^{29}$ In the government's new strategy, the term refers to the oil and gas industry, the maritime industry (including ships and other floating units), as well as the seafood industry. In 2017, the Ministry of Trade, Industry and Fisheries and the Ministry of Petroleum and Energy jointly launched an "ocean strategy" [havstrategi], an initiative given the heading "New growth, proud history." ${ }^{0}$

Government policies can lay the foundation for success or failure, but they cannot determine the result. Luckily, the Norwegian maritime milieu is much more than political decisions. Norway's coastline is still among the longest in the world, and around 80 per cent of the Norwegian population lives less than 10 kilometres from the sea. The Norwegian area at sea is six times larger than the country itself. Norwegian businesses continue to look for ways to profit from the sea, and the ocean-based industries make up more than 70 per cent of Norwegian export revenues,

\footnotetext{
${ }^{29}$ Norway, Ministry of Trade, Industry and Fisheries, 2015, Maritime muligheter - blà vekst for grønn fremtid.

${ }^{30}$ A report published in 2016 - "Norway - the ocean nation" - starts off with an bold claim: "Norway is the leading ocean nation in the world"; Norges Rederiforbund et al. $(2016,3)$. The government's new maritime strategy is more modest; "Norway is one of the leading ocean nations in the world"; Norway, Ministry of Trade, Industry and Fisheries/Ministry of Petroleum and Energy, 2017, Ny vekst. Stolt historie, 6. It is worth noting that the report "Norway - the ocean nation" is a joint publication by the Norwegian Shipowners' Association and four other industry associations, covering manufacturing, petroleum, fish farming and fishing.
} 
37 per cent of the private sector's Gross Domestic Product and 14 per cent of private sector employment. ${ }^{31}$

In other words, the sea has a larger presence-in daily life and in the economy-than in most other countries. This geographic advantage is unlikely to change in the 21 st century.

The second advantage is the maritime traditions and heritage, and the manner in which the long history of Norwegian shipping shapes selfperception and occupational and investment choices. It was this tradition that created the maritime cluster, and it was this tradition that enabled the building up of capital and competence. As suggested above, maritime history is nowadays getting more intertwined with "maritime culture."

Norway is the home of world-leading shipping companies and associated businesses. These are seen as interesting places to work, and thus manage to attract qualified people that in other countries would have preferred other sectors. Moreover, the existence of a maritime infrastructure-practical and theoretical education, research, networks and so on-facilitates recruitment to the shipping sector.

The maritime heritage and culture is not static. So far, the critical mass of the shipping companies and their partners has been sufficient for the shipping sector to regenerate itself. ${ }^{32}$ Moreover, the manner in which the various "ocean industries" have started to cooperate can be seen as a means to ensuring that a critical mass is maintained. It is also a way of increasing the value added. Given the development of traditional deepsea shipping, where countries have competed to attract activity, many of the mechanisms that gave economic benefits in the 20th century have disappeared or been reduced. Among these are both the ability to extract large tax revenues from shipping companies and the employment effect of seafarers in the deep-sea fleet. The land-based activities are therefore increasingly important, and it would be beneficial if these could be linked to other ocean-based industries to ensure critical mass.

However, one part of maritime culture is eroding: the number of people with actual experience of the sea is declining rapidly. The shipping

\footnotetext{
${ }^{31}$ Norway, Ministry of Trade, Industry and Fisheries/Ministry of Petroleum and Energy, 2017, $N y$ vekst. Stolt historie, 6.

${ }^{32}$ This is one of the main points in Norman (2012).
} 
companies and the authorities have tried to introduce measures that can alleviate this - recruitment drives, cadet positions, compensation for the use of Norwegian seafarers and tax breaks. Norway prides itself on its maritime competence, and this competence has traditionally been transferred from the sea to the shore. When Norwegian shipping built up its international position, the captains that went ashore and started their own companies were crucial. In the post-war period, seafarers came ashore with skills and knowledge that made them valuable assets in the daily operation of the business. They became managers, port captains, supervisors, surveyors and consultants.

Today, the on-board competence-in a purely Norwegian setting-is disappearing. By far the highest proportion of those working on the NIS vessels are foreigners. Most shipping companies have outsourced the employment of seafarers to management companies abroad. We do not know how this will affect the future of the industry, but it is unlikely to have a positive impact. Employment in Norwegian waters goes some way towards alleviating the negative development, but even this part of the business is "threatened" by foreign labour.

As a result of the rich maritime history, Norwegian companies and individuals have a maritime identity and awareness that stands out in an international perspective. This maritime culture is, however, the most volatile and vulnerable of the three advantages.

In Chap. 2, we divided the cultural dimension into a "maritime culture" element and a "Norwegian culture" element. While the first of these has changed quite a lot, in particular during the past decades, there are still aspects of the "Norwegian culture" that differ from other countries. Consequently, the third and final element that might make the country competitive within shipping and other maritime industries is therefore the specific "Norwegian culture." Important aspects are egalitarianism, gender equality and governance.

Norway continues to be relatively egalitarian, despite its strong wealth and income growth. Egalitarianism is reflected in, among other things, a compressed wage structure. Unskilled labour is relatively expensive and highly educated labour is relatively cheap. The compressed wage structure implies that Norwegian shipping, despite a high overall wage level, might in fact have a competitive advantage when it comes to the price of 
competence. When we adjust for productivity, the costs of using Norwegian engineers, for instance, is not necessarily higher than in countries with a much lower general wage level.

The relatively low price of high-quality skills can be a competitive advantage, not only for shipping companies, but also for many of the auxiliary industries that are related to shipping. Banking, insurance, marine equipment production and so on are all high competence and high value-added industries. Moreover, Norway is at the international forefront with regard to maritime research, with technological and operational innovations that spill over into business.

The egalitarian attitude is also reflected in questions of gender. Norway and the other Nordic countries rank among the top three in the world on indices that measure differences between men and women, such as the Gender Inequality Index and the Global Gender Gap Index. ${ }^{33}$ Gender equality can be an advantage for economic and business development-it makes little sense to choose skills and competence from only half of the population. Moreover, diversity is more likely to reduce groupthink. ${ }^{34} \mathrm{At}$ the same time, with regard to gender, Norwegian business is not as progressive as, for example, politics and education, despite policies such as quotas at Board level in stock exchange listed companies. While 45 per cent of the ministers in the Norwegian government are women-including all of the three most important posts-only 5 per cent of the 100 largest companies listed on the Oslo Børs have female chief executive officers.

The shipping sector is known for being particularly conservative-at the international level it is 20 years behind other businesses, according to one female insider. ${ }^{35}$ Still, this implies that there is scope for improvement, and Norway has a shorter way to go than many other countries. In 2008 the Bergen shipowner Elisabeth Grieg became the first female President of

\footnotetext{
${ }^{33}$ Nordic Council of Ministers $(2017,12)$.

${ }^{34}$ Although most studies find no statistically significant effects of female participation on profits, a recent analysis of more than 22,000 companies from more than 90 countries suggest that "the presence of women in corporate leadership positions may improve firm performance"; Noland, Moran and Kotschwar $(2016,3)$.

${ }^{35}$ Tradewinds, 14032018. Of the Fortune 500 companies, only 6 per cent are headed by women, and "the inequality is even higher in shipping"; Tradewinds, 25012018.
} 
the Norwegian Shipowners' Association, and she has taken an active stand in promoting women in business. Today, there are several initiatives that aim to encourage and support women who work in shipping, including female-focused organizations and mentoring programmes.

The final cultural element that might make Norwegian maritime industries competitive is governance and social capital. Efficient and accountable politicians and bureaucrats, as well as the (relative) absence of corruption, characterize Norwegian economy and business. The combination of high social capital — trust, norms and networks - and good governance has been used to explain the economic success of Norway and the other Nordic countries. ${ }^{36}$ It can be used as a competitive advantage in shipping and other maritime industries.

\section{Finally: Summing Up}

What are the lessons from the 20th century development? How can a small country such as Norway remain competitive in the world's most global industry?

Norwegian shipping was competitive at the beginning of the 20th century due to a favourable starting point. The combination of geography, history and culture enabled the Norwegians to take advantage of the strong growth of seaborne trade in the second half of the 19th century. In other words, when the 20th century began, the Norwegian shipping community had a head start.

Norwegian shipping remained competitive by becoming less Norwegian. By embracing markets abroad, by attracting foreign capital, and by combining domestic competence and technology with labour from low-cost countries, the country's shipping companies managed to hold on to market shares and ensure profitability.

In a shipping world where the playing field has been levelled, and national differences have almost been wiped out, perhaps Norwegian shipping can maintain competitiveness by embracing the distinctively

\footnotetext{
${ }^{36}$ Nordic Council of Ministers (2017, 14-17).
} 
Norwegian elements again: a vast maritime sector, where shipping is complemented by industries that harvest the resources of the ocean; a national bias towards shipping and the sea; a compressed wage structure; and an egalitarian society, with gender equality, good governance and high social capital. Geography, history and culture.

\section{Bibliography}

D. Bakka (2017) Nasjonens are - Norsk rederinaring mellom marked og politikk (Bergen: Bodoni Forlag)

L. Borgersrud \& I.B. Eriksen (2015) Sabotører i vest-Sabotasjeorganisasjonen på Vestlandet 1940-1945 (Bergen: Bodoni Forlag)

K. Fasting (1955) AS Moltzaus Tankrederi (Oslo: AS Moltzaus Tankrederi)

L.R. Fischer (2016) 'The International Merchant Marine in Comparative Perspective: An Analysis of Canada and Norway, 1870-1900', in Schifffahrt und Handel/Shipping and Trade: Vorträge, gehalten anlässlich der Verabschiedung von Lars U. Scholl in den Ruhestand im März 2012 (Bremen: Edition Falkenberg) 77-99

G. Harlaftis \& I. Theotokas (2009) Leadership in World Shipping: Greek Family Firms in International Business (Basingstoke: Palgrave Macmillan)

G. Iversen (2011) 'Inventing the nation: Diorama in Norway 1888-1894', Early Popular Visual Culture, 9:2, 123-129

J.E. Klepsland (2011) Utvikling av eierstrukturen i rederier notert på Oslo Børs (Bergen: Stiftelsen for samfunns- og næringslivsforskning)

K. Larsen (1948) A History of Norway (Princeton: Princeton University Press)

T. Lennerfors, H. Lindgren \& R.T. Poulsen (2012) 'The Two Declines of Swedish Shipping', in S. Tenold, M.J. Iversen \& E. Lange (eds) Global Shipping in Small Nations: Nordic Experiences after 1960 (Basingstoke: Palgrave Macmillan) 100-128

Menon (2017) Maritim verdiskapningsbok 2017 (Oslo: Menon Business Economics)

M. Noland, T. Moran \& B. Kotschwar (2016) 'Is Gender Diversity Profitable? Evidence from a Global Survey', Working Paper 16-3 (Washington DC: Peterson Institute for International Economics)

Nordic Council of Ministers (2017) Is the Nordic region best in the world? (Copenhagen: Nordic Council of Ministers) 
Norges Rederiforbund (2015) Norske offshorerederier - i krevende farvann (Oslo: Norges Rederiforbund)

Norges Rederiforbund et al. (2016) Havnasjonen Norge (Oslo: Norges Rederiforbund, Norsk Industri, Norsk olje og gass, Sjømat Norge, Norges Fiskarlag)

V.D. Norman (2012) 'A Future for Nordic Shipping?' in S. Tenold, M.J. Iversen \& E. Lange (eds) Global Shipping in Small Nations: Nordic Experiences after 1960 (Basingstoke: Palgrave Macmillan) 202-214

H.W. Nordvik (1997) 'From Benign Neglect to Active Intervention: Norwegian Government Shipping Policies from the 1970s Shipping Crisis to the Present', unpublished manuscript (Bergen: Norwegian School of Economics and Business Administration)

A.S. Svendsen (1976) Skipsfartskrisen (Bergen: Institute for Shipping Research)

S. Tenold (2015) Geared for Growth. Kristian Gerhard Jebsen and His Shipping Companies (Bergen: Bodoni Forlag)

Open Access This chapter is licensed under the terms of the Creative Commons Attribution-NonCommercial-NoDerivatives 4.0 International License (http:// creativecommons.org/licenses/by-nc-nd/4.0/), which permits any noncommercial use, sharing, distribution and reproduction in any medium or format, as long as you give appropriate credit to the original author(s) and the source, provide a link to the Creative Commons license and indicate if you modified the licensed material. You do not have permission under this license to share adapted material derived from this chapter or parts of it.

The images or other third party material in this chapter are included in the chapter's Creative Commons license, unless indicated otherwise in a credit line to the material. If material is not included in the chapter's Creative Commons license and your intended use is not permitted by statutory regulation or exceeds the permitted use, you will need to obtain permission directly from the copyright holder. 